\title{
THE SOCIAL DEMOCRATIC FEDERATION AND POPULAR AGITATION AMONGST THE UNEMPLOYED IN EDWARDIAN MANCHESTER
}

The Social Democratic Federation ${ }^{1}$ is usually regarded by historians as of only marginal importance to the working-class movement of the later nineteenth and early twentieth centuries. To support this view reference is often made to its naive and mechanistic interpretations of Marxist theory, ${ }^{2}$ its small membership and sectarian nature, ${ }^{3}$ and the futility of its concentration upon political activity amongst the unemployed at the expense of support for the industrial action of trade unionists and the Parliamentary representation of labour. ${ }^{4}$ The stereotype of a narrow, doctrinaire sect with incompetent leadership contains more than a grain of truth, but like most stereotypes conveys only a partial verity. Too often it is used as an excuse for neglecting the SDF on the precept that it was irrelevant and "misguided" in its conception of the right path for the working-class movement. The comparative failure of the SDF, however, owed at least as much to the deeply engrained reformist and trade-unionist tradition amongst the English working class as it did to the inadequacies of the SDF itself. ${ }^{5}$

1 The title SDF is used throughout in preference to the dual usage of SDF and SDP. The Social Democratic Federation changed its name to Social Democratic Party in 1907.

2 H. Collins, "The Marxism of the Social Democratic Federation", in: Essays in Labour History 1886-1923, ed. by A. Briggs and J. Saville (1971), pp. 47-69; W. Kendall, The Revolutionary Movement in Britain 1900-21 (1969), ch. 1.

${ }^{3}$ For membership see P. A. Watmough, "The Membership of the Social Democratic Federation 1885-1902", in: Society for the Study of Labour History Bulletin, No 34 (1977), pp. 35-40. The view that it was elitist and sectarian is remarkably general, see for example Z. Bauman, Between Class and Elite (1972), pp. 183-84, 214-15, and E. J. Hobsbawm, "Hyndman and the SDF", in Labouring Men (1964), p. 233.

4 Collins, "The Marxism of the Social Democratic Federation", loc. cit.; H. Pelling, The Origins of the Labour Party (1965), p. 57.

5 The history of the SDF is often compared with the contrasting fortunes of German social democracy during the same period. On the significance for the SDF of the reformist tradition in England see Hobsbawm, "Hyndman and the SDF", loc. cit., and Kendall, The Revolutionary Movement in Britain, op. cit. 
The study of the SDF has in fact suffered from an over-emphasis upon views drawn from its impressive range of contemporary critics (from Engels to Keir Hardie), and from a marked concentration on the activities and idiosyncracies of its leaders, especially the silk-hatted Henry Hyndman. ${ }^{6}$ The SDF was, contrary to the prevalent stereotype, a decentralised organisation with significant branch autonomy. There was a diversity of political philosophy and practice, and such local studies as exist have given the lie to the notions that the SDF shunned conventional union activity, or washed its hands of either public office (whether local or national) or co-operation with the Independent Labour Party. ${ }^{7}$ An interpretation based solely upon the national figures and nationally devised policy is inevitably incomplete. An aspect of this neglect of the SDF has been the inadequate picture which we have of its popular agitation amongst the unemployed. Apart from a national survey, which is of necessity general in nature, and accounts of the riots of 1886 in London there is little to go on. ${ }^{8}$ It is the purpose of this paper by means of a local study to focus attention on this central, but neglected, element in SDF policy.

In his autobiography Henry Hyndman, the founder of the Social Democratic Federation, wrote:

From the start of the modern Socialist movement in Great Britain [...] Social Democrats have devoted more attention to the question of the unemployed than to any other matter whatever. Nearly all our principal agitations, demonstrations, and collisions with the "authorities" have arisen from our efforts in this direction. ${ }^{9}$

The formative years of the SDF during the economic depression of the 1880's made "street politics" (open-air meetings, marches and demonstrations) directed at organising the unemployed seem a promising area for paving the way to social revolution. Yet such action also involved more short-term objectives. From its beginnings SDF policy combined a desire to see the transfer to public ownership of the means of production and

${ }^{6}$ It is significant that the only major study of the SDF concentrates on its founder and leader Henry Hyndman: C. Tsuzuki, H. M. Hyndman and British Socialism (1961).

7 See especially P. Thompson, Socialists, Liberals and Labour (1967), ch. 6 (on London), S. Yeo, Religion and Voluntary Organisations in Crisis (1976), ch. 10 (on Reading), and the local studies of working-class politics in Lancashire and Manchester and Salford cited below.

8 The role of the SDF in the development of national labour policies for the unemployed is considered in K. D. Brown, Labour and Unemployment (1971).

9 H. M. Hyndman, Further Reminiscences (1912), pp. 252-53. 
distribution with a willingness to campaign for "palliatives", which Hyndman had referred to in 1883 as "stepping stones to a happier period". ${ }^{10}$ Thus, SDF campaigns pressurised schoolboards to provide meals for school children, encouraged boards of guardians to liberalise relief scales, and pressed municipal authorities to demolish slums and build their own housing. These locally elected authorities were regarded as being more directly vulnerable to working-class pressure than was the remoter authority of central government. "Municipalisation" was itself a "palliative" which, along with others, was seen as lessening the evils of the existing regime so that the workers could put more energy into the fight for fundamental change. ${ }^{11}$ This aspect of SDF theory should be taken into account when assessing SDF agitation amongst the unemployed.

SDF agitation amongst the unemployed fluctuated with the cycle of unemployment. The dependence upon a volatile and fluctuating audience made SDF campaigns seem little more than sporadic and often desperate propaganda exercises with no hope of continuity, or of striking deep roots in the working class. The futility of agitation amongst the unemployed was to frustrate even the most stalwart of activists, but incitement to revolt was only one aspect of the SDF rationale for such agitation..$^{12}$ More prosaically, it was also intended to promote the campaign for short-term "palliative" measures, in particular, the expansion of unemployment relief and the provision of public works for the unemployed. Moreover, given that the control of relief agencies was in the hands of locally elected bodies, it is not surprising that some SDF branches should have initiated their own campaigns to pressurise these authorities.

Most previous assessments of popular agitation amongst the unemployed in late-nineteenth- and early-twentieth-century Britain have concentrated on the development of central-government policy. Some historians have remarked upon the apparent effectiveness of demonstrations and riots in wringing concessions from a troubled central authority. ${ }^{13}$ whereas, by contrast, others feel they have identified an enduring governmental indifference to popular agitation and comment on the severe limitations of political action based upon the support of the

10 Tsuzuki, Hyndman and British Socialism, op. cit., pp. 50-51. See especially the Manifesto issued after the West End riots of 8 February 1886, and Hyndman's 1887 pamphlet. A Commune for London.

11 Collins. "The Marxism of the Social Democratic Federation", p. 64.

${ }^{12}$ See G. Stedman Jones. Outcast London (1971), pp. 343-45, on the lack of revolutionary potential amongst the unemployed.

${ }^{13}$ For example. on the impact of the London riots of 1886 see B. B. Gilbert. The Evolution of National Insurance in Great Britain (1966), p. 38, Brown, Labour and Unemployment, op. cit. pp. 59-62, and Stedman Jones, Outcast London, p. 298. 
unemployed.$^{14}$ Yet much analysis of this sort overlooks the local nature of such popular agitation, and in particular the SDF's perceptive (if confused) awareness of the decentralised character of much State power in the nineteenth century. In emphasising the need to pressurise local agencies of State authority (e.g., boards of Poor Law guardians, municipal authorities and the police) the SDF implicitly recognised the limited role assigned to the central State apparatus. Considering, in particular, that relief strategies for the unemployed were locally administered and directed, and that this fact was acknowledged by all government legislation prior to 1909 (the Unemployed Workmen Act of 1905 was based upon the two existing networks of local administration - borough councils and boards of guardians), it is important to turn to local studies when assessing the significance of the SDF connection with the unemployed movement.

Unemployment was often seen by contemporaries as being at the root of the "social problem" in the late-nineteenth-century city. The structure of the labour market was, however, little understood before the end of the century. ${ }^{15}$ This was particularly true of the phenomenon of underemployment. There existed within all major cities a pool of unskilled casual and seasonal labour. The well-known pattern of casual labour on the docks of London ${ }^{16}$ was parallelled by a confusing variety of casualised occupations in the warehouses and workshops of major city centres. At times of cyclical unemployment it was the casual poor rather than the archetypal "honest workingman" who sought charity and applied for poor relief. ${ }^{17}$ These were the raw material for SDF "street politics".

After the work of G. Stedman Jones it is usually assumed that the largest casual-labour market was to be found in the East End of London. The sheer size of the capital city makes comparison with provincial centres unrealistic. Nonetheless preliminary research based on the occupationalclassification system adopted in nineteenth-century censuses suggests that amongst the major industrial and commercial cities outside London it was Manchester which possessed a casual labour market which, as a proportion of the total labour-force, was greater than that in any other inland city. ${ }^{18} \mathrm{It}$

14 J. Harris, Unemployment and Politics (1972), especially pp. 55-56 and 83-84.

15 Ibid.. ch. 1 .

16 Stedman Jones, Outcast London, pp. 111-26.

17 For a survey of the urban labour market and the place within it of underemployment, see J. H. Treble. Urban Poverty in Britain 1830-1914 (1979), ch. 2. Periods of cyclical unemployment during this period are usually identified as 1885-86, 1892-95, 1902-05 and 1908-10.

18 See my essay "Outcast Manchester", in: City, Class and Culture: Social Policy and Cultural Production in Victorian Manchester, ed. by A. J. Kidd and K. W. Roberts (forthcoming. 1985). 
should not, therefore, be surprising to find that Manchester witnessed recurrent and often violent public disturbances by "the unemployed", their ranks swollen by the "cast offs" from an overstocked casual-labour market.

From the mid 1890's it was the Lancashire branches which had been the most important arena for SDF activity outside London. ${ }^{19}$ There had been branches in Manchester and Salford from the early days. A branch in Salford (later the South Salford SDF) was established in 1884 and a Manchester branch (based on the Rochdale Road area) was formed during the winter of 1885-86. From the beginning street campaigns were a central feature of SDF activity in Manchester and Salford. During the unemployment crises of 1884 and 1886-87 the SDF organised mass demonstrations. In March 1886 in a speech seconded by John Burns, J. H. Hall demanded public works for the unemployed, the liberalisation of outrelief, municipal housing and the eight-hour day. ${ }^{20}$ Local SDF campaigns in the 1880's and early 1890's consisted of public meetings and demonstrations designed to put pressure on the local authorities. ${ }^{21}$

The Trafalgar Square riots of 1886 are often associated with SDF agitation amongst the unemployed. ${ }^{22}$ It was the SDF emphasis upon direct action which is usually seen as distinguishing it most clearly from the Independent Labour Party in the 1890's and 1900's. In general terms this is true. Yet a characteristic feature of the labour and socialist movement in Manchester and Salford has been identified as the degree of co-operation that existed between the ILP and the SDF in the late 1890's and early 1900's. This co-operation not only extended to electoral politics, but for some involved the continuing prospect of a united socialist party culminating in the formation of the British Socialist Party following a Socialist Unity conference held in Manchester in 1911.23 This apparent unity

19 This has been clear for some time, but see especially J. Hill, "Social Democracy and the Labour Movement: The Social Democratic Federation in Lancashire", in: North West Labour History Society Bulletin, No 8 (1982), p. 44; Watmough, "The Membership of the Social Democratic Federation", loc. cit.

20 Justice, 6 March 1886.

21 For the origins and general history of the SDF in Manchester and Salford see G. C. Goldberg, "The Socialist and Political Labour Movement in Manchester and Salford 1884-1914" (M.A. thesis, Manchester University, 1975); see also J. Hill, "Working Class Politics in Lancashire, 1885-1906" (Ph.D. thesis, Keele University, 1971).

22 For the riots and SDF policy formation see Tsuzuki, Hyndman and British Socialism, pp. 72f., 76f.; Pelling, The Origins of the Labour Party, op. cit., pp. 41-45; Stedman Jones, Outcast London, pp. 290-96.

23 See D. Morris, "The Origins of the British Socialist Party", in: North West Labour History Society Bulletin, No 8, pp. 29-43, and N. Reid, "Manchester and Salford ILP: A more controversial aspect of the pre-1914 period", ibid., No 5 (1979), pp. 25-31. 
probably had much to do with the distinctly socialist origins of the Manchester and Salford ILP. ${ }^{24}$ Yet such unity had a patchy history after the emergence of the Manchester and Salford Labour Representation Committee in $1903 .{ }^{25}$ Reflecting growing unease amongst socialists about the "Labour Alliance", criticism of Labour Party policy on unemployment ran high in Manchester and Salford, and was voiced within the local ILP itself. ${ }^{26}$ After 1903, however, the issue of unemployment had the chief effect of accentuating the divergence of policy between ILP and SDF elements within the working-class movement. It was, moreover, accompanied by a revival of SDF fortunes in Manchester.

The South Salford SDF remained the largest single branch in the area with an average membership of around two hundred, ${ }^{27}$ but soon several new branches were established in Manchester and this revival can be directly related to the unemployed movement of those years. Members of the Hulme branch, which changed its name to South-West Manchester in 1901 , were foremost in the agitation. ${ }^{28}$ A Manchester Central branch was formed in $1903,{ }^{29}$ but the major increase in SDF organisation followed the unemployment agitation of 1903-05. Between 1905 and 1908 six new branches were formed in working-class districts. A North-East Manchester branch covering Ancoats, Miles Platting, Newton Heath, Beswick and Bradford was founded in $1906,{ }^{30}$ and subsequently branches were established in Stretford, Gorton, Longsight, Ardwick and Harpurhey. Despite the existence of ten branches in the district there developed little in the way of effective co-ordination, each branch acting as it felt fit according to its own interpretation of policy and circumstances. ${ }^{31}$ Furthermore, the increase in the number of branches may not have been paralleled by a corresponding acceleration in membership. Membership details for the SDF are notoriously difficult to establish and the inference is inescapable that the numbers remained low. Yet agitation amongst the unemployed

24 This is the view of Reid, "Manchester and Salford ILP", pp. 26-27.

25 Only the South Salford SDF was affiliated to the LRC.

26 This found expression in articles in Labour Leader and ultimately in the so-called Green Manifesto of 1910, see Reid, "Manchester and Salford ILP", p. 28.

27 Justice, 30 October 1908. This branch may, however, have benefited from a local agreement with the ILP whereby a territorial demarcation left activity in South Salford to the SDF in return for a free hand for the ILP in West Salford. See Reid, "Manchester and Salford ILP", p. 27.

28 Justice, 16 March 1901; see also A. Woolerton, The Labour Movement in Manchester and Salford (1907).

29 Justice, 26 December 1903.

30 Ibid., 12 May 1906.

31 See for example ibid., 3 October 1908, letter from Will Hughes. 
depended upon the energy and commitment of small groups of individuals, and the prominence of the SDF in Manchester during the economic crises of 1903-05 and 1908-10 was chiefly due to the role played by party activists in organising the local unemployed. It is this campaign of popular agitation which is the concern of the remainder of this paper.

In his evidence to the Royal Commission on the Poor Laws Walter Long, ${ }^{32}$ speaking of 1904 and 1905, reminded the Commissioners that "during the eighteen months that the pressure of the unemployed was growing the methods adopted by the unemployed towards the authorities, municipal and Poor Law, were violent and extreme. There were crowds besieging the offices of the relieving officers and boards of guardians in London, Leeds, Liverpool, Manchester and Birmingham and all great cities." Many local authorities, Long said, had constantly called his attention to the plight of the unemployed and their agitation. ${ }^{33}$ In Manchester, at least, there had been little real agitation before the autumn of 1904. When disturbances did break out, the local authorities assumed that their own municipal labour registry was the culprit.

Labour registries were not labour exchanges. They were a common municipal response to the unemployment crises of the 1890's and 1900's, and confined to the collection of names in connection with the allocation of relief work. Manchester's labour registry was established in 1903 in response to a "sleeping-out" crisis during the previous winter. ${ }^{34}$ It opened its doors on 29 December, and within eight weeks 3,700 men had registered as unemployed. By February 1904 every morning "several hundred men of the outdoor worker class" were gathering at the Albert Street Police Station looking for relief work. ${ }^{35}$ Many on the City Council feared the re-opening of the registry in the autumn of 1904 . They saw it as a threat to the established social order, since there was "an element of danger in the gathering together of starving men in such numbers and affording them the opportunity of talking over their troubles[;] it was just this sort of thing that sometimes led to revolution in city and in state." ${ }^{36}$ The Chief Constable of Manchester, Robert Peacock, later confirmed this view. In May 1905

32 Walter Long (1854-1924), Conservative MP, 1880-1921, President of the Local Government Board 1900-05 and 1915-16.

${ }^{33}$ Royal Commission on the Poor Laws and the Relief of Distress, Appendix, Vol. VIII [Cd 5066] (1910), q. 78466.

${ }^{34}$ See my "Outcast Manchester", loc. cit., for the "sleeping-out" crisis.

35 Manchester Evening News (hereafter MEN), 26 February 1904.

36 Ibid., 7 October, Council views as communicated to his board by the Chairman of the Chorlton guardians, Francis Chandler. 
he told the Departmental Committee on Vagrancy that having a labour registry meant "that every morning you have about two thousand men assembling at one centre; you get the men together; the least spark would set these men rioting; whereas if there was no labour registry the men would be scattered about." ${ }^{37}$ It was indeed the gathering together of large numbers of unemployed men achieved by the setting up of the corporation labour registry and the subsequent promise of relief works that led to public disorder. Disturbance, however, was minimal before November 1904 and the local authorities were largely indifferent to the unemployed lobby. The catalyst which turned this body of men into a political force was the intervention of members of the SDF.

Despite the large numbers registered as unemployed during the winter of 1903-04, the men remained quiet and unobtrusive, and the Manchester City Council did little to provide relief work for them. The total receipts of the Lord Mayor's Relief Fund established in February 1904 came to only $£ 561 .^{38}$ The Lord Mayor, Thomas Thornhill Shann, felt sufficiently confident to reject as unnecessary a petition calling for a public meeting on the unemployment problem. They must be careful, he told the deputation which presented the petition, not to "attract a class of people who were always tired. [...] it must not be assumed that all the unemployed want work. ${ }^{39}$ During the early weeks of the following winter the City Council resisted suggestions that the provision and finance of relief works was the proper task of the corporation. Yet the refusal of local boards of guardians to approve a poor-rate subsidy for a municipal programme of "necessary public work" $" 40$ left many City Councillors feeling in a "cleft stick" on the issue. ${ }^{41}$ The Salford City Council had set up a committee to assess the

37 Report of the Departmental Committee on Vagrancy [Cd 2891] (1906), q. 7883. Peacock was Chief Constable from 1898 until his death in 1926. He was formerly Chief Constable of Oldham borough police. His period of authority in Manchester coincided with the establishment of an increasingly independent administrative role for the Manchester police. Peacock was latterly regarded as the doyen of provincial Chief Constables and was knighted in 1919.

38 Royal Commission on the Poor Laws, Appendix, Vol. XIX [Cd 4795] (1909), Appendix I.

39 MEN, I March 1904. Shann (1846-1923) was a "self-made man". Born in Ancoats, he became a successful textile merchant and was a Conservative councillor from 1897, being elected Lord Mayor in 1903. He served for two terms and was knighted upon the King's visit to Manchester in 1905.

40 Manchester Guardian, 15 October 1904. Poor Law guardians were officially prohibited from giving outdoor relief to the unemployed except in return for a labour test. see Harris, Unemployment and Politics, op. cit., pp. 147-50, and my "Outcast Manchester" for local Poor Law policy.

41 MEN, 14 October 1904. 
possibilities of increasing the municipal labour-force. ${ }^{42}$ In Manchester Council deliberations resulted in the sanction of a special Paving Committee scheme which would ultimately employ 700 to 800 men. This, however, would take some time to organise and meanwhile the labour registry would remain closed. ${ }^{43}$

The Manchester City Council had reluctantly accepted responsibility for unemployment relief, and began the process of preparing relief works. But these plans would take some time to come to fruition. Some of the envisaged works would not be ready before Whitsun week 1905 . Meanwhile it became increasingly apparent that unemployment was at unprecedented levels. Estimates by Labour Councillor Tom Fox that in working-class districts $5.4 \%$ of heads of families were out of work, giving a total of ten thousand plus dependents, were widely reported in the press. The seriousness of the situation was borne out by the publication of investigations such as that undertaken by a Presbyterian minister in working-class districts off Oxford Street and Stretford Road. A survey which specifically excluded streets occupied by "very casual" labourers none the less discovered cases of unemployment in $22.5 \%$ of houses visited. ${ }^{44}$

It was in the autumn of 1904 that the SDF began its campaign of agitation to secure a special meeting of Parliament to discuss the unemployment situation. Local branches were urged to summon public meetings and to provide statistical backing by carrying out censuses of the unemployed. ${ }^{45}$ In appealing for local agitation Justice, the journal of the SDF, claimed that "there is a better prospect than ever before of waking up the authorities to a sense of their responsibility in regard to the unemployed [...], and it is our duty to see to it that we bring the requisite pressure to bear upon them." 46 Despite the call for an autumn session of Parliament to discuss unemployment the SDF also felt that the local agencies should be pressurised into expanding relief. Such pressure should include the Poor Law authorities, indeed, "In the proper application of the machinery of the Poor Law lies the solution of the unemployed problem." Poor relief should be properly organised and should not pauperise or disfranchise recipients. In addition, the "bourgeois-created prejudice against the Poor Law on the part of the working classes themselves" must be "broken down by agitation and education". 47

42 Proceedings of the Salford City Council 1903-04, p. 609.

43 Proceedings of Manchester City Council 1904-05, I, pp. 112-13.

44 MEN, 29 October 1904.

45 Brown, Labour and Unemployment, p. 37.

46 Justice, 15 October 1904.

47 Ibid., 27 May 1905. 
A campaign of agitation designed to put pressure on local relief agencies to expand provision was begun by the SDF in Manchester in November 1904. It focussed at least as much on the local boards of guardians as it did upon the municipal authority, and in a remarkably short period of time it achieved quite striking results. Unemployed unrest in the city was marked in the aftermath of Council promises of relief works. Attention focussed on the various corporation committees which had committed themselves to some sort of provision. On 14 November 1904 the Paving Committee depot at Bridgewater Street was "besieged" by hundreds of men in search of work who, when they had been turned away, marched to Albert Square to demand work of the Lord Mayor. ${ }^{48}$ On 16 November two SDF activists, J. B. Hitchen and W. E. Skivington, organised and led a march of two thousand unemployed men across Manchester towards the Town Hall. An SDF deputation met the Lord Mayor, whilst the assembled unemployed waited outside in Albert Square. They were not to be disappointed, for the deputation secured a promise that the labour registry would open on the following Monday. ${ }^{49}$

The re-opening of the labour registry gave the SDF activists the regular forum they required. Without it, it would have been much harder for them to organise the unemployed and thereby pressurise the authorities. Their early success enabled the local SDF to secure the confidence of the unemployed. An Unemployed Committee was elected by a show of hands. Its Chairman was Hitchen, its Secretary was Skivington, both of the SouthWest Manchester branch of the SDF. ${ }^{50}$ Soon the meetings they convened became very large. Five thousand gathered in Stevenson Square on Sunday 20 November 1904 and agreed to march on the offices of the Chorlton board of guardians on the following Wednesday. ${ }^{51}$ Hitchen had told a previous meeting that if the guardians would not provide relief then they "should go as a body to the workhouse and demand work or admittance to the House". ${ }^{52}$ It is surely no coincidence that a conference of local guardians meeting with the Lord Mayor on 21 November agreed temporarily to raise the outdoor-relief scales from four shillings to six shillings. The clerk

48 MEN, 14 November 1904.

49 Ibid., 16 November.

50 Both were shopkeepers. I have found out little about Hitchen other than that he was a confectioner. William Edward Skivington's shop was in Hulme. He was arrested after the riot of 31 July 1905 and served a brief term of imprisonment. At this time he was a Chorlton guardian and later was appointed as a Poor Law representative on the Manchester Distress Committee; he gave evidence to the Royal Commission on the Poor Laws. Skivington died suddenly in 1910 at the age of forty-two.

51 MEN, 22 November. The offices were near the city centre.

52 Ibid., 16 November. 
to the Chorlton board wrote personally to Skivington asking him to call off the planned march on the board's offices in the light of this decision. ${ }^{53}$ Despite this plea two thousand marched to the Chorlton offices at All Saints in order "to fix responsibility for finding work and food on the right shoulders". They chanted the SDF slogan "Work not charity". A deputation secured a promise that Chorlton guardians would petition the Local Government Board to enable them to grant relief without disfranchisement, and immediate relief in kind was given to those who wanted it. The unemployed were urged, however, to focus their attention on the City Council, who, they were told, was the appropriate body to find work for them. ${ }^{54}$ Pressure on the municipal authority mounted when the labour registry re-opened and 2,500 men attempted to register on the first day. ${ }^{55}$ It took over a week before they could all be registered, and by the end of November the register contained 3,175 names. A frenzy of corporation activity provided relief work for over six hundred within a week. ${ }^{56}$

Thus, as I have described, there were mass demonstrations in Manchester during November 1904 of a type not seen for a generation. By contrast, events in Salford were much more low-key. An Unemployed Committee formed in December 1904 rejected SDF involvement. The number registering as unemployed, however, was only slightly up on the previous year, and there was little support for the campaign of the Salford Unemployed Committee. ${ }^{57}$ Moreover, the development of a municipal relief programme was leisurely. In Manchester, the local relief agencies were galvanised into activity. The Poor Law offices were besieged and outdoor-relief scales raised; relief in kind was freely distributed to unemployed demonstrators by the Chorlton guardians. Numerous deputations saw the Lord Mayor to demand work. The labour registry was re-opened in response to an SDF request and corporation committees were desperately endeavouring to put together a programme of relief works. The unemployed had emerged as a political force. The SDF campaign to pressurise the local authorities into expanding relief provision had in the short term proved remarkably successful. The degree of their success is perhaps best measured by the effect the campaign had on the generosity of Manchester's charitable middle class. Another Lord Mayor's Fund was launched during the last week of November 1904. Whereas earlier in the

53 Ibid., 21 November.

54 Ibid., 23 November.

55 Ibid., 21 November.

56 Ibid., 28 November.

57 Salford Reporter, 3, 4 and 9 December. 
year the receipts of a previous fund had totalled only $£ 561$, this time over $£ 2,600$ was contributed within the first two weeks and the final total exceeded $£ 7,000 .{ }^{58}$ Shann, the Lord Mayor, believed this fund had contained the unrest. He told the Royal Commission on the Poor Laws that it had "undoubtedly relieved many thousands of deserving people, and to a large extent it allayed for some time serious agitation that had arisen in Manchester due to the want of employment". ${ }^{59}$

Another reason why the agitation declined was the policy of the SDF itself. The local leadership was anxious to play its part in the party's national campaign, the intention of which was to identify central government as the authority responsible for the unemployed. Skivington and other leaders of the Unemployed Committee obtained interviews with Liberal leader Sir Henry Campbell-Bannerman and Prime Minister Arthur Balfour when they visited Manchester during the winter of 1904-05. ${ }^{60}$ They pressed Balfour to support their own scheme, devised by Arthur Smith, for a nationwide system of compulsory labour bureaux empowered to find work or provide sustenance. ${ }^{61}$

The SDF national campaign had the effect of diverting attention from the local agitation. There was a marked relaxation of pressure on the local authorities. The Lord Mayor exploited to the full this opportunity to raise the siege of the local relief authorities. He convened a conference of unemployed representatives at the Town Hall. At his initiative a committee was formed to promote Arthur Smith's scheme. It consisted of Smith, Hitchen and Skivington, but was to be chaired by Shann himself. ${ }^{62}$ The new committee resolved to petition Parliament to bring forward a bill based on Smith's proposals. Public meetings were to be held at "respectable" venues in order to organise public opinion. ${ }^{63}$ The Lord Mayor was clearly envisaged as having a key role in this campaign. He was to preside at public meetings. More significantly, he even joined the Unemployed Committee itself in an ex officio capacity. The first of the public meetings was held in St James' Hall and was addressed by Henry Hyndman ${ }^{64}$ It was

58 MEN, 9 December.

59 Royal Commission on the Poor Laws, Appendix, Vol. VIII, p. 293.

${ }^{60}$ MEN, 29-30 November, and Labour Leader, 9 December (for Campbell-Bannerman); MEN, 7 January 1905 (for Balfour).

${ }_{61}$ MEN, 10 December 1904; Justice, 4 February 1905. Arthur Smith moved from the ILP to the SDF over the issue of unemployment. His bill enshrined the "right to work" principle, whereby once a man was registered as unemployed it would be the duty of the local authority to provide him with work or maintenance.

62 MEN, 10 December 1904.

63 Manchester Guardian, 16 December.

64 MEN, 20 December; see also Hyndman, Further Reminiscences, op. cit., p. 279. 
later to be suggested that "the movement was being kept 'on the hang' purposely by the Mayor and his friends to tide over the critical period of the winter" ${ }^{65}$ Doubtless each side thought they were using the other. The SDF was keen to obtain official support for their national campaign. The Lord Mayor was equally happy to divert attention away from the local and towards the central power, and by January 1905 he had resigned all his positions in the campaign, his objectives, perhaps, achieved. There were no more large demonstrations that winter. Energies were now concentrated on the campaign over the Conservative government's own unemployment proposals as announced in the King's speech to Parliament on 14 February.

It is tempting to wonder what would have happened if the SDF had persisted with its campaign to pressurise the local authorities rather than switching to more "constitutional" channels and national objectives. It was, of course, characteristic that the SDF should dissipate its energies in this manner. Its local agitation in Manchester had achieved a significant expansion of relief provision, and may have been able to secure further concessions from confused and nervous local officials. In future years the local authorities were generally able to isolate the SDF from the unemployed and control both by police action. Only again during the winter of 1908-09 was the SDF to regain the leadership of Manchester's unemployed and to pose a significant threat to public order within the city. By then, however, they faced local authorities which had learned how to control the unemployed without the need for major concessions.

A national campaign conducted by the labour and socialist movement over the Conservative government's Unemployed Workmen Bill culminated in a massive programme of meetings organised by the Labour Representation Committee between May and August 1905. This campaign absorbed the attention of local activists in all sectors of the movement. It was the famous demonstration and riot of 31 July 1905 that re-ignited the situation in Manchester. ${ }^{66}$ On $31 \mathrm{July}$, in contravention of police instructions, the Unemployed Committee held a mass meeting in Albert Square, with Victor Grayson as guest speaker. The meeting was also addressed by Skivington and Smith of the South-West Manchester SDF. These two subsequently

65 Labour Leader, 4 August 1905. The approval shown the Manchester movement at this time by the ILP's own newspaper reflects the joint ILP-SDF activities following the riot of 31 July, see below.

66 For an account of this demonstration and an assessment of its significance in the development of central-government policy see Brown, Labour and Unemployment, pp. 59-62, and id., "Conflict in Early British Welfare Policy: The Case of the Unemployed Workmen Bill of 1905", in: Journal of Modern History, XLIII (1971), pp. 615-29. 
led a large body of men up Market Street, the main thoroughfare in Manchester, effectively blocking it to traffic. The police dispersed the crowd by use of baton charges, and arrested the leaders for obstruction and assault. The scenes of riot were said to have "no parallel in the history of the city since the dreadful days of Peterloo". ${ }^{67}$ Keir Hardie also made use of this analogy in a telegram of congratulations to the organisers of the demonstration. He tought that since the spirit of Peterloo was once more abroad they would now win their fight. ${ }^{68}$

The disturbance of 31 July 1905 was the first of many over the next four years which involved police action against the unemployed. All the local SDF leaders of the Unemployed Committee at one time or another were to appear in court and several spent time in prison. In November 1904 SDF agitation with mass support had gained rapid concessions from uncertain and nervous authorities. It is significant, however, that from an early stage control of the unemployed and regulation of their meetings was in the hands of the police. The municipal labour registry (and thereby control over the admission to relief work itself) was directly administered by the police and was based in police stations. The authorities had obvious reasons for keeping Albert Square (where the Town Hall was situated) free from demonstrations. As early as 23 November 1904 the Unemployed Committee had been told that they could no longer hold meetings there. Instead the police made available their own premises, the Albert Street Police Yard. ${ }^{69}$ In addition meetings could be held in Stevenson Square on weekday evenings between 7 p.m. and 10 p.m., and on Sundays. Several times the leaders of the unemployed petitioned the Watch Committee to reverse this decision, in particular requesting permission to hold Sunday meetings in Albert Square. ${ }^{70}$

Police regulation of unemployed meetings in this way was a constant bone of contention for the local SDF leadership. Numerous attempts were made to break out of the strait-jacket it imposed. Meetings which gathered in Albert Square or Piccadilly were swiftly broken up and arrests for obstruction were frequent. Even minor infringements of police restrictions could earn swift retribution, as when in September 1909 a baton charge was used to disperse a meeting in Stevenson Square which had continued beyond the 10 p.m. deadline. ${ }^{71}$ The larger the meeting, of course, the more

67 Manchester Evening Chronicle, 31 July 1905.

68 Brown, Labour and Unemployment, p. 59.

69 MEN, 23 November 1904.

${ }^{70}$ Epitome of the Proceedings of Council Committees, Watch Committee, 31 August and 14 September 1905.

71 MEN, 1 September 1909. 
difficult it was to break up. During the height of the unemployment crisis of 1908 Albert Square was repeatedly invaded by thousands of the unemployed, and the police had resort to baton charges on several occasions and not always with great success.

The Manchester unemployed movement itself was given a great boost by the events of 31 July. The immediate result was greater co-operation between the SDF and representatives of the ILP. The Labour Leader called it an "Entente Cordiale". ${ }^{72}$ Prior to this there had been scant co-operation over the unemployed. Although Skivington publicly regretted a lack of SDF-ILP unity on the issue, ${ }^{73}$ local Labour councillors were sharply critical of SDF activists, whom they had dubbed "the Stevenson Square demagogues". ${ }^{74}$ However, the situation appeared changed after 31 July. A link was made between activity in Manchester and the much weaker unemployed movement in neighbouring Salford. In September 1905 a Manchester and Salford Unemployed Committee was formed, which numbered forty-five delegates from local branches of the ILP and SDF as well as the Manchester and Salford Women's Social and Political Union, the Manchester and Salford Women's Trade Council, and other bodies. ${ }^{75}$ The sense of outrage caused by the treatment accorded the demonstrators on 31 July had thus, for the moment, united many sections of the local labour and socialist movement behind a campaign of direct action on behalf of the unemployed. Significantly, however, the two SDF leaders who had been arrested that day, Skivington and Smith, were excluded from the new joint committee, which was dominated by the ILP. The chief figures on the new committee were A. Dunckley of Central branch ILP and W. C. Anderson of the Shop Assistants Union (later a member of the ILP national executive). ${ }^{76}$

Under ILP direction the Manchester and Salford Unemployed Committee discarded the former policy of pressurising the authorities through public demonstrations, and instead reverted to deputations to the Lord Mayor, corporation committees and, after October 1905, the Manchester Distress Committee newly established in accordance with the Unemployed Workmen Act. ${ }^{77}$ The major points made by these deputations in 1905 and 1906 were complaints about the Distress Committee's

${ }^{72}$ Labour Leader, 18 August 1905.

73 Justice, 17 June.

74 Ibid., 11 February.

75 Labour Leader, 25 August; MEN, 14 September.

76 MEN, 18 September.

77 For the Unemployed Workmen Act of 1905 see Harris, Unemployment and Politics; Gilbert, The Evolution of National Insurance, op. cit. 
failure to initiate relief work on its own account rather than through corporation committees. The limitations of the "three day week" and "sixteen week" rules under the Unemployed Workmen Act were also complained of, and one deputation felt it was "unjust and undignified" that public work should be done at reduced wages paid out of charitably subscribed funds. They repeatedly and strongly objected to police control of the labour registry. ${ }^{78}$

The "Entente" between the ILP and the SDF was somewhat onesided. The exclusion of the militant SDF leaders from the Unemployed Committee had the effect of isolating the SDF from the main body of the unemployed in Manchester. W. E. Skivington had been appointed to the Distress Committee as a delegate from the Chorlton board of guardians (he had been elected a guardian in April 1905). In this position he joined with Labour members (unsuccessfully) to obtain a more radical interpretation of the clauses of the Unemployed Workmen Act. His comrades in the SDF wanted to do the same by returning to a policy of "unconstitutional" pressure. But their action met with little support from the unemployed. In November 1905 an attempt to hold a meeting in the proscribed venue of Albert Square resulted in the arrest of Arthur Smith and others for obstruction. They were subsequently imprisoned in default of paying their fines. Smith told the court that they would "do everything short of murder to make themselves felt", but his frustration at lack of support was apparent when he complained that the unemployed were "cowards for suffering as they do". ${ }^{79}$

The new joint Unemployed Committee actually did very little to coordinate activities between Manchester and Salford. It served little purpose and had disintegrated by the end of 1906. It had no significant impact on the development of local policy on the unemployed, although it may have acted as a mechanism for expressing specific points of discontent. Very little was done under the provisions of the Unemployed Workmen Act during the winters of 1905-06, 1906-07 and 1907-08. SDF agitation dribbled on, but the easier employment situation of these years had taken the sting out of their campaign. Crowds at SDF meetings in Stevenson Square grew smaller and smaller, and oratory grew proportionately more desperate and extreme. Smith declared in February 1906 that the unemployed must be "red hot revolutionists" if they were to obtain a solution to the problem of unemployment. He urged them not to be apathetic: "We must not walk around with our hands in our pockets." He feared that the

78 MEN, 27 November 1905, 6 February and 16 October 1906.

79 Ibid., 14 November 1905. 
unemployed were being bought off by charity. The Central Hall authorities of the Manchester and Salford Methodist Mission had been "offering soup and buns to stop the unemployed agitation". 80

The failure to arouse mass support for an unemployed campaign between 1906 and the summer of 1908 led Arthur Smith into more and more extreme and marginal activities. He organised a series of "land grabs", i.e. the illegal occupation and cultivation of private land by groups of the unemployed. These attempts at what Smith called "communalism" were more for propaganda purposes than anything else. His intention was to draw attention to the plight of the unemployed, who, he claimed, were starving while valuable private land lay uncultivated. ${ }^{81}$ These experiments were short-lived and the "communalists" were soon evicted. There was little support for such a campaign. Arthur Smith's propaganda activities continued until they reached a climax in the summer of 1908, when he and three other SDF activists were convicted on charges of conspiring to destroy private property.

They had organised a campaign of shop-window smashing in order to draw attention to the plight of the unemployed. The smashing of shop and warehouse windows had reached epidemic proportions and the large number of such crimes reported in the local press cannot all have been organised by the SDF. None the less, Smith had clearly been given a deal of attention by the local authorities. A police spy gave evidence in the case, and the defendants admitted considering the use of explosives, the kidnapping of an Alderman as well as an intensified programme of window smashing in order to put pressure on the authorities. Despite protest meetings held while the trial was in progress ${ }^{82}$ the prison sentences of twelve months each were meant to be punitive and exemplary. ${ }^{83}$ The epidemic of window smashing was indicative of increasing social unrest. Unemployment was higher during the spring and summer of 1908 than it had been for over twenty years. The breaking of plate-glass windows as social protest is perhaps a sign of frustration. It may be significant that the first instance of crime came just three days after the defeat of the Labour Party's own Unemployed Workmen Bill on 13 March $1908 .^{84}$ As the Labour Leader noted, these were "the growing symptoms of social revolt". 85

80 Ibid., 7 February 1906.

81 Justice, 21 July.

82 Clarion, 3 April 1908.

83 MEN, 8 April.

84 Ibid., 17 March.

85 Labour Leader, 3 April. 
During 1908, as the extent of unemployment became clearer, the Manchester Distress Committee was under pressure to take some action. The ILP estimated that 15,000 adult male workers in the city were unemployed in August 1908, and this was before the expected autumn slump. ${ }^{86}$ The experience of previous years had made it plain to the City Council that they could not avoid responsibility for unemployment relief. Moreover, since unemployment was clearly going to be very high, public relief works would have to planned earlier than ever and on a much larger scale. Accordingly, the Council approved an ambitious scheme to request borrowing powers from the Local Government Board to the tune of $£ 50,000 .{ }^{87}$ As in 1904, the Council made its decision in principle on unemployment relief before any campaign of agitation had begun. Subsequently, however, the authorities were subjected to a series of mass demonstrations which in the event exceeded in size and ferocity anything the city had seen in 1904 or 1905. The SDF still provided the leadership of the agitation. Arthur Smith, however, was still in Strangeways Prison and W. E. Skivington now played only a small part in the campaign. The most prominent activists in 1908 were Leopold Fleetwood, an engineer from the General Electricity Company works in Salford, and James Dunning. ${ }^{88}$

The real danger to the authorities came during September 1908, when public order was seriously threatened. Attention was securely focussed on the municipal authority. The intention was to force an expansion of relief provision in line with borrowing powers sanctioned by the Local Government Board, and to obtain the removal of the labour registry from police control. Although disorder was much greater than in 1904, there were in the event fewer concessions from the civic authority. The issue of control focussed starkly on the relationship between the police and the unemployed, and at times took the form of a battle between the two. It was not difficult for the SDF to organise mass demonstrations among the unemployed in September 1908. The police were already finding it hard to control the unemployed who gathered seeking relief work in the Albert Street Police Yard. Fleetwood and other SDF activists would address the two to three thousand men who gathered in the Yard each morning in the hope of work.

On one occasion, they led the men out of the Yard on a march to Piccadilly. Rather than disperse the crowd the Chief Constable followed

86 MEN, I September. Estimates varied, the Clarion, 25 September, put the figure at 11,000 .

87 MEN, 2 September.

88 Dunning took on particular responsibility for organising the single men amongst the unemployed, who were generally not granted relief work. 
them and appealed for calm. ${ }^{89}$ Two days later Fleetwood led a demonstration of three thousand unemployed men in an attempt to "crowd" Manchester Cathedral during Evensong in response to some critical remarks Dean Welldon had made about the unemployed. The service was broken up and Fleetwood addressed the men with an "unemployed prayer". Afterwards, the men marched up Market Street carrying Fleetwood shoulder-high. Police failed to disperse the crowd despite using mounted police and batons..$^{90} \mathrm{~A}$ subsequent demonstration of over three thousand unemployed men in Albert Square sent a deputation to see Councillors and civic officials including the Chief Constable and Chairman of the Watch Committee. This demonstration was itself illegal, since Albert Square was still a proscribed meeting place. None the less in a climate of unrest the deputation was heard. They demanded that the labour registry be removed from police control, that the Distress Committee labour colony at Chat Moss should be expanded, and that there should be a Town's Meeting called to consider the unemployment question. The other issues were deferred for consideration, but a Town's Meeting was agreed to and arranged for the following Friday..$^{91}$

The SDF kept up the pressure. On the day after the authorities had agreed to call a Town's Meeting, three thousand unemployed men marched from the Albert Street Police Yard to the Manchester Workhouse in New Bridge Street. The men were rowdy and police reinforcements barely prevented a forcible entry into the building. ${ }^{92}$ The police were only just in control. There is clear evidence of animosity towards the police themselves. The Chief Constable had even found it necessary to admonish the registered unemployed for insulting and spitting at police officers when they crossed the Albert Street Yard. Police morale was at a low ebb. ${ }^{93}$ The authorities were particularly alarmed by SDF attempts to unite the unemployed of Manchester with those in Salford. Several meetings took place at which Fleetwood and Dunning addressed the unemployed from both cities. They urged the men at one meeting in Unwin Square in Salford to arm themselves at demonstrations using "knives, pokers and crowbars against police batons". ${ }^{94}$ One evening, two meetings combined and a crowd of six thousand unemployed from both Manchester and Salford

\footnotetext{
89 MEN, 11 September.

90 Ibid., 14 September.

91 lbid., 21 September.

92 Ibid., 22 September

93 Ibid., 23 September.

94 Ibid., 18 September.
} 
marched in a disorderly fashion through the streets of the city. ${ }^{95}$ This period of unrest culminated in the events of the evening of the Town's Meeting, and these are worth relating in some detail.

On the evening of the Town's Meeting several thousands had gathered outside the Town Hall in Albert Square awaiting the outcome. Fleetwood and five other representatives of the unemployed sat, alongside the Lord Mayor, on the platform inside. The Lord Mayor assured the meeting that everything possible was being done for the unemployed: the Lord Mayor's Relief Fund had raised the sum of $£ 1,200$ in the first seven days of the appeal, seven hundred and fifty men were already engaged on relief works, and it was hoped that another five hundred could be taken on within the week. The authorities had feared that the meeting might be the occasion for a show of strength by the unemployed. Anticipation that the meeting might be "packed" by the unemployed themselves had led officials to cover frescoes and paintings in the Town Hall. Outside, eight hundred policemen guarded the entrances and wooden barricades had been placed across Albert Square. Their fears were not without justification, for whilst the Town's Meeting proceeded speakers harangued the crowd from the steps of the Albert Memorial. At 7 p.m. a bugle was sounded, apparently as a signal, and the Town Hall was rushed. Police prevented entry, and the main gates were shut. Police reinforcements were called for and the Square cleared. This only exacerbated the problem of control, since the crowd simply marched through the city streets. They soon broke into a run, and a number of windows were smashed by stones in Cross Street and Deansgate by a crowd that was now cheering and shouting and quite out of control. Individual policemen were attacked. Some of the crowd rushed the Midland Hotel, but the doors were shut just in time. By 9 p.m. the crowd had re-assembled in Albert Square. When Fleetwood emerged from the Town Hall, he was carried shoulder-high to the Albert Memorial steps and addressed the crowd. Police, fearing further instances of riot, attempted to arrest Fleetwood. A formation of fifty officers broke through the crowd and seized him. But the crowd almost immediately seized him back. A baton attack failed to prevent Fleetwood being carried away to Stevenson Square, where six thousand gathered to hear his report on the Town's Meeting. ${ }^{96}$

On this occasion the police had failed to maintain public order. They had temporarily lost control of the streets and failed to prevent damage to private property. They had either to re-assert their authority or face the

95 Ibid., 23 September.

96 Manchester Guardian, 25 September; MEN, 25 September. 
consequences of civil riot. The civic authorities gave express instructions to the Chief Constable to re-establish the rule of law. Action taken by the police on the following night was consciously intended as a show of force. They claimed to have got wind of a proposed assault on the Town Hall, and were ready when Fleetwood led a large body of unemployed men into Albert Square. Immediately the men assembled they were dispersed by a succession of baton charges. Police struck out hard and numerous bystanders were also beaten. Attempts by the crowd to re-assemble in Piccadilly, Stevenson Square and Oldham Street were broken up by mounted police. Posses of police ran through the streets breaking up all streetcorner gatherings. For several days no meetings of the unemployed were allowed to continue. The mere cry of "police" was sufficient to send hundreds stampeding. The Infirmary dealt with numerous injuries to face and head. ${ }^{97}$ The police justified their action as a necessary response to "a preconceived plan to attack the Town Hall". They claimed that many of the crowd had carried weapons, and claimed to have recovered several pieces of iron, open knives, a heavy pestle and a burglar's jemmy from the square after the demonstration. Significantly, however, they also saw their action as a means of stemming the increasing tide of "inflammatory speeches", which were seen as a serious menace to public order. ${ }^{98}$ The Lord Mayor rejected several demands for a public inquiry despite the number of bystanders who had been injured. ${ }^{99}$

The police had regained control of the streets. Subsequent demonstrations were contained without much difficulty. The local authority had thus made effective use of the police to control and regulate the action of the unemployed. This was not limited to the control of public demonstrations. The labour registry itself remained in police hands. In 1908 the Chief Constable was often present at meetings between civic officials and unemployed leaders. Police responsibility for the unemployed was extended into other areas. The Chief Constable even made an appeal through the press to local employers and householders, asking them to do all they could to find or create work for as many of the unemployed as possible. ${ }^{100}$ Resentment against the police is clear in some actions of the unemployed. But local-authority faith in the ability of the police to control the agitation

\footnotetext{
97 Manchester Guardian, 26 September; MEN, 26 and 28 September, 7 October.

98 MEN, 28 September.

99 Ibid., 28 October; Manchester Guardian, 29 October.

100 MEN, 22 September.
} 
was justified not only in their capacity to control the streets, but also to isolate agitators from the main body of the unemployed. At the same time as police action was being used to curtail unemployed demonstrations in the autumn of 1908 the SDF were being excluded from the Albert Street Police Yard. Fleetwood was refused admittance since he was from outside the area, i.e. Salford, and Dunning was found relief work despite being a single man. ${ }^{101}$ Soon Fleetwood was arrested for inciting the unemployed to steal. ${ }^{102}$ Ultimately a new Unemployed Committee was elected which excluded all with a police record. This effectively barred Fleetwood and most of the SDF activists. ${ }^{103}$ Despite a recurrence of window smashing by unemployed youths, which resulted in several arrests, the campaign of agitation for that winter was by and large over. ${ }^{104}$

In 1909 and 1910 further disturbances occurred, although on a smaller scale. The initiative, however, was now in the hands of the authorities. The primary focus of attention was the right of the SDF to use various locations for their public meetings. Occasionally battles between police and unemployed broke out, as when in September 1910 police attempting to clear Stevenson Square were pelted with stones, bottles and bricks by a disorderly crowd of unemployed men. ${ }^{105}$ Such SDF agitation amongst the unemployed came to be regarded in the public imagination as a question of public order. There was, moreover, little opportunity to pressurise the local authorities. Unemployment was less marked than in the previous few years, and the advent of a new central-government policy on unemployment relieved the local authorities of primary responsibility for the unemployed. Manchester City Council, however, continued to use a body of the unemployed each year until 1914 as a form of cheap labour on necessary public works. It was not until the 1920's that the local relief agencies, especially the Poor Law guardians, once more came under pressure from the unemployed.

The SDF campaign of popular agitation amongst the unemployed of Manchester had achieved the predictable result of public disorder and even riot. Success in securing the palliative of an expansion of unemployed relief was, however, uneven. In the event the role of the police had proved crucial; initially in their regulation and monitoring of the unemployed through the supervision of registration procedures, and ultimately through

\author{
101 Ibid., 15 October. \\ 102 Ibid., 17 October. \\ 103 Ibid., 26 October. \\ 104 Ibid., 9 October. \\ 105 Manchester Guardian, 26 September 1910.
}


their control of the streets which, once achieved, enabled them to effectively strait-jacket the SDF campaign. ${ }^{106}$

The violence and social unrest of the pre-1914 period is well-known. Strike riots and suffragette protest have, however, overshadowed the earlier unemployed agitation. Yet the State persisted in dealing with the unemployed and the underemployed through the existing local authorities. The SDF's unemployment campaign, designed to secure the palliative of improved relief provision, although ultimately unsuccessful, should not therefore be dismissed as misguided or irrelevant in its original conception. The SDF sought the fullest possible exploitation of existing relief mechanisms as well as a re-structuring of the unemployment policy of central government. The Labour Party campaign in Parliament on behalf of the unemployed was far from inspiring. Direct action thus fulfilled the raison d'être of the SDF's "palliative" policy. Demonstrations were in most cases conceived and organised by local activists, and functioned primarily as an attempt to pressurise those local representatives of State power who seemed more immediately threatened by popular agitation than their distant governors in Whitehall and the Houses of Parliament.

106 This degree of police involvement was not typical of the relief mechanisms adopted in major cities. Investigators for the Royal Commission on the Poor Laws praised this aspect of Manchester's policy. Royal Commission on the Poor Laws, Appendix, Vol. XIX, Appendix I, p. 466. 